Received: 2016.12.14 Accepted: 2017.02.14 Published: 2017.05.04

\title{
Mucosa-Associated Lymphoid Tissue (MALT) Lymphoma of the Colon: A Case Report and a Literature Review
}

Authors' Contribution:

Study Design A

Data Collection B

Statistical Analysis C

Data Interpretation D

Manuscript Preparation E

Literature Search F

Funds Collection G
EF 1 Hafsa Abbas

E 2 Masooma Niazi

E 3 Jasbir Makker
1 Department of Medicine, Bronx Lebanon Hospital Center, Bronx, NY, U.S.A. 2 Department of Pathology, Bronx Lebanon Hospital Center, Bronx, NY, U.S.A. 3 Department of Medicine, Division of Gastroenterology, Bronx Lebanon Hospital Center, Bronx, NY, U.S.A.
Corresponding Author: Conflict of interest:
Hafsa Abbas, e-mail: hafsabbas20@gmail.com

None declared

\section{Patient: Female, 56 \\ Final Diagnosis: \\ Symptoms: \\ Medication: \\ Clinical Procedure: \\ Specialty: \\ Colonic MALT lymphoma \\ Epigastric pain \\ Colonoscopy and biopsy \\ Gastroenterology and Hepatology}

Objective:

Background:

Case Report:

Conclusions:

MeSH Keywords:

Full-text PDF:

\section{Rare disease} ment is not well established. olution of the MALT lymphoma. Lymphoma, B-Cell, Marginal Zone
Non-Hodgkin lymphoma (NHL) is a well-known hematologic malignancy. The gastrointestinal (Gl) tract is the most commonly involved extra nodal site. MALT lymphomas are uncommon, accounting for $5 \%$ of all NHL. Gastric mucosa-associated lymphoid tissue (MALT) lymphoma is the prototype seen in association with Helicobacter pylori. Colonic MALT lymphoma is rare and comprises only $2.5 \%$ of the MALT lymphomas. Its etiology and treat-

A 56-year-old Hispanic woman presented to the clinic with symptoms of chronic epigastric pain for the past three years and a 13-pound weight loss over the past two months. The patient did not have any prior medical conditions. Her systemic examination was unremarkable, while her routine labs revealed mild anemia. An upper endoscopy and colonoscopy for colorectal cancer screening were performed revealing erosive gastropathy with duodenal ulcers and a $5 \mathrm{~cm}$ broad based polypoid mass in the hepatic flexure respectively. Computed tomography (CT) of the abdomen revealed a round, well demarcated mass at the hepatic flexure of the colon. The histopathology and immunophenotyping were consistent with extra nodal marginal zone of MALT lymphoma. Stool testing for $H$. pylori was positive. The patient received two weeks of $H$. pylori eradication therapy and four cycles of rituximab. Repeat colonoscopy after completion of chemotherapy showed complete res-

Unlike gastric MALT lymphoma, treatment of colonic MALT lymphoma is not standardized. Chemotherapy and surgical resection have been utilized to successfully treat it. Only a handful of cases have reported successful treatment of colonic MALT lymphoma with rituximab monotherapy.

Colonic Neoplasms • Gastrointestinal Neoplasms • Helicobacter pylori •

http://www.amjcaserep.com/abstract/index/idArt/902843

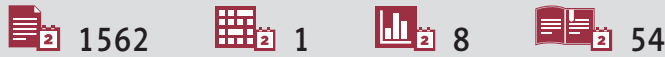




\section{Background}

Non-Hodgkin Lymphoma (NHL) has an extra nodal presentation in about one third of cases. The gastrointestinal (GI) tract is the most commonly involved extra nodal site, particularly the stomach [1-4]. Lymphoma of the mucosa-associated lymphoid tissue (MALT) and diffuse large B cell lymphoma (DLBCL) are the two most common varieties of the lymphomas involving the Gl tract [5]. MALT lymphomas are uncommon, accounting for $5 \%$ of all NHL [6,7] and gastric MALT lymphoma is the prototype of this group [8], seen in the setting of chronic inflammation and is associated with Helicobacter pylori infection $[9,10]$. Colonic MALT lymphoma is a rare entity, and comprises only $2.5 \%$ of MALT lymphomas [7,11]. The etiology and treatment is not well established. We report here on a case of MALT lymphoma of the colon successfully treated with chemotherapy.

\section{Case Report}

A 56-year-old Hispanic woman presented to the gastroenterology clinic of our hospital to schedule her screening colonoscopy. During the visit, she also reported chronic epigastric pain for the past three years. The patient had been generally well without any prior medical conditions until three years ago when these symptoms began. She described the pain as localized to the epigastric region, crampy, intermittent without any precipitating factors. There was no association with intake of food or bowel movement but symptoms were relieved sometimes with histamine receptor-2 blockers or proton pump inhibitors.
There was no nausea, vomiting, diarrhea, constipation, fever, early satiety, or appetite changes. However, she reported a 13 pound weight loss over two months. There was no history of smoking, alcohol use or illicit drug use. The patient did not have a personal history of hepatitis $\mathrm{C}$, autoimmune diseases, or colon carcinoma. Her uncle and grandfather had a history of cancer. Premedication included calcium and vitamin D supplements, and ranitidine.

On examination, her temperature was $36.6^{\circ} \mathrm{C}$, her blood pressure was $117 / 70 \mathrm{~mm} \mathrm{Hg}$, her pulse rate was 72 beats per minute, and her respiratory rate was 14 breaths per minute. Her abdomen was non distended, soft, with mild tenderness in the epigastrium, and her bowel sounds were normal. The rest of the systemic examination was unremarkable. Results of laboratory parameters are given in Table 1.

Computed tomography (CT) of abdomen and pelvis was performed after intravenous administration of contrast material and it revealed a round, well demarcated soft tissue focus associated with the hepatic flexure of the colon $(3.9 \times 2.7 \times 3.2 \mathrm{~cm})$ (Figures 1, 2). An upper endoscopy and colonoscopy were performed. The upper endoscopy revealed few nonbleeding gastric atrum erosions and multiple clean based duodenal ulcers. The colonoscopy revealed a $4 \mathrm{~cm}$ broad based polypoid mass in the hepatic flexure (Figure 3), and two diminutive rectal polyps. Histopathologic examination of the gastric antrum erosions biopsy revealed chronic gastritis and inflammation (CLO test negative). The rectal polyps were hyperplastic in nature, and the biopsy specimen from the hepatic flexure mass revealed colonic mucosa with dense lamina propria infiltrates of small

Table 1. Initial laboratory work-up.

\begin{tabular}{|c|c|c|c|c|c|}
\hline Parameter & $\begin{array}{l}\text { Initial laboratory } \\
\text { results }\end{array}$ & $\begin{array}{l}\text { Reference } \\
\text { range }\end{array}$ & Parameter & $\begin{array}{l}\text { Initial laboratory } \\
\text { results }\end{array}$ & $\begin{array}{l}\text { Reference } \\
\text { range }\end{array}$ \\
\hline Hemoglobin(g/dl) & 12.1 & $12-16$ & $\begin{array}{l}\text { Blood urea nitrogen } \\
(\mathrm{mg} / \mathrm{dL})\end{array}$ & 20 & $6-20$ \\
\hline Hematocrit (\%) & 34.9 & $42-51$ & Creatinine (mg/dL) & 0.7 & $0.5-1.5$ \\
\hline Platelet count (k/ul) & 259 & $150-400$ & Total protein $(\mathrm{g} / \mathrm{dL})$ & 8.3 & $6-8.5$ \\
\hline $\begin{array}{l}\text { White blood cell count } \\
\text { (per } \mathrm{mm}^{3} \text { ) }\end{array}$ & 6.8 & $4.8-10.8$ & Albumin (g/dL) & 4.7 & $3.2-4.8$ \\
\hline Sodium (mEq/L) & 137 & $135-145$ & Alanine transaminase (U/L) & 22 & $5-40$ \\
\hline Potassium (mEq/L) & 4.1 & $3.5-5.0$ & $\begin{array}{l}\text { Aspartate transaminase } \\
(\mathrm{U} / \mathrm{L})\end{array}$ & 28 & $9-48$ \\
\hline Bicarbonate (mEq/L) & 29 & $24-30$ & Alkaline phosphatase (U/L) & 190 & $53-141$ \\
\hline Chloride (mEq/L) & 99 & $98-108$ & Bilirubin Total (mg/dL) & 0.3 & $0.2-1.2$ \\
\hline Calcium (mEq/L) & 9.4 & $8.5-10.5$ & Bilirubin Direct (mg/dL) & 0.1 & $0.2-1.2$ \\
\hline Glucose (mg/dL) & 91 & $70-120$ & Lipase (U/L) & 42 & $<61$ \\
\hline
\end{tabular}




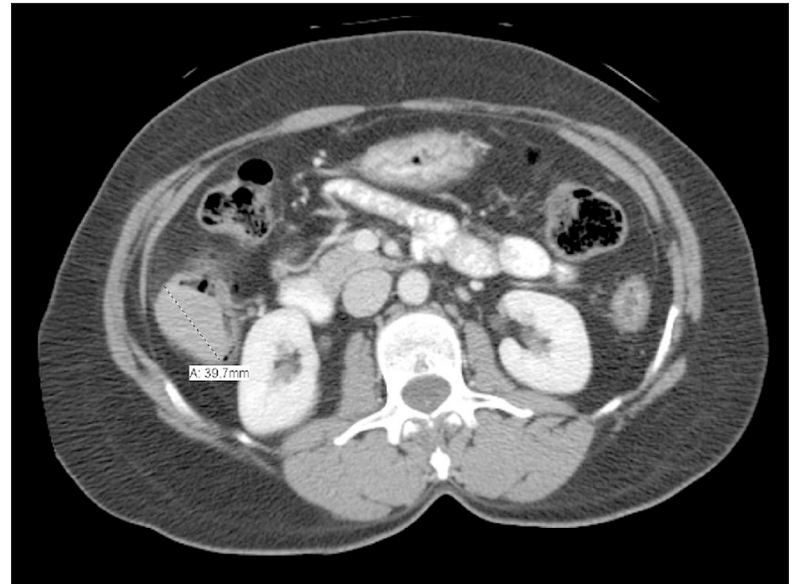

Figure 1. Computed tomography (CT) of abdomen (horizontal view) showing a colonic mass at the hepatic flexure (size appreciated with the help of a ruler).

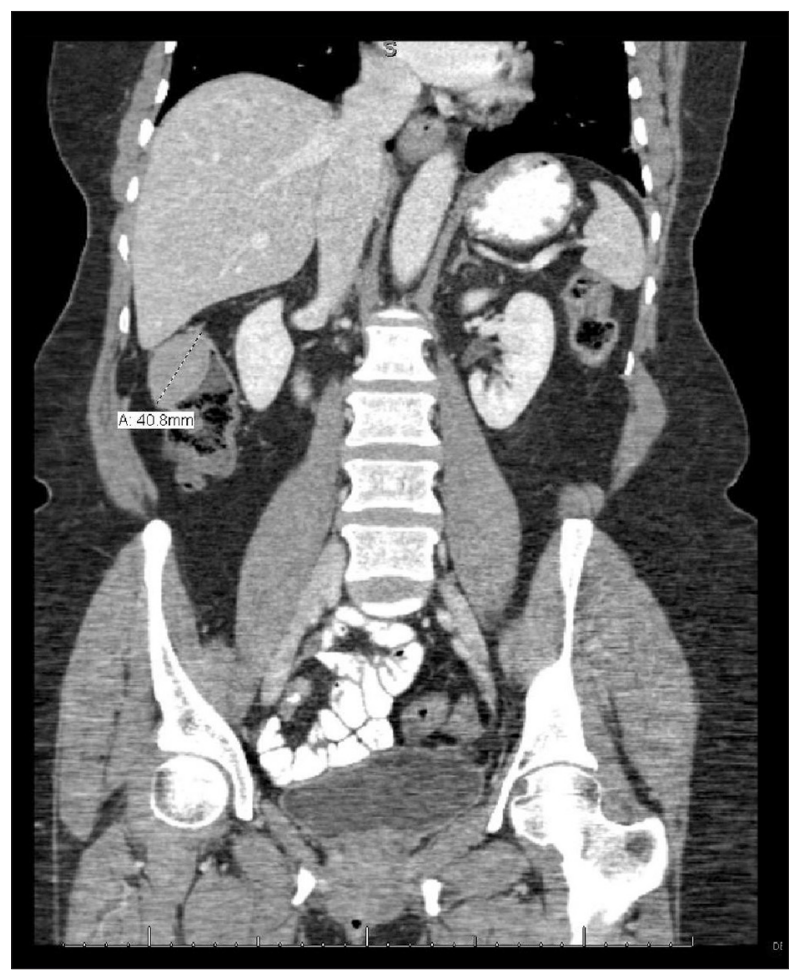

Figure 2. Computed tomography (CT) of abdomen (coronal view) showing a colonic mass at the hepatic flexure (size appreciated with the help of a ruler).

to medium sized lymphocytes extending into the submucosa, focal lymphoepithelial lesions, and plasma cells (Figure 4). Immunohistochemical stains of the biopsy specimen showed extensive infiltrates of B cells positive for CD20 (Figure 5), CD79a, and CD19. The immunophenotyping and the morphological findings were consistent with extra nodal marginal zone of MALT lymphoma. Biopsies obtained during the upper endoscopy did not reveal H. pylori; however, stool testing was

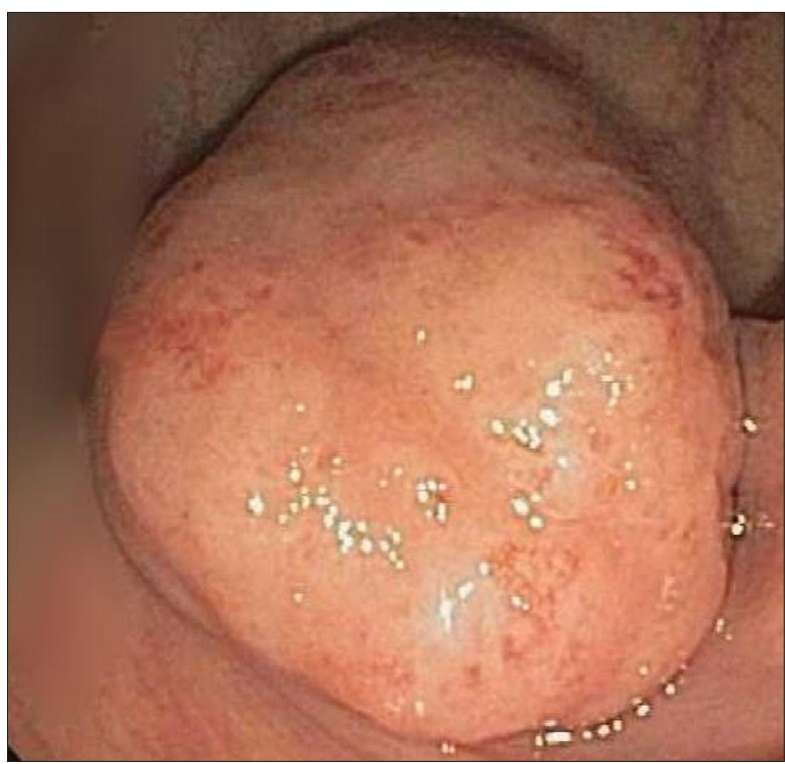

Figure 3. Colonoscopic image of hepatic flexure MALT lymphoma.

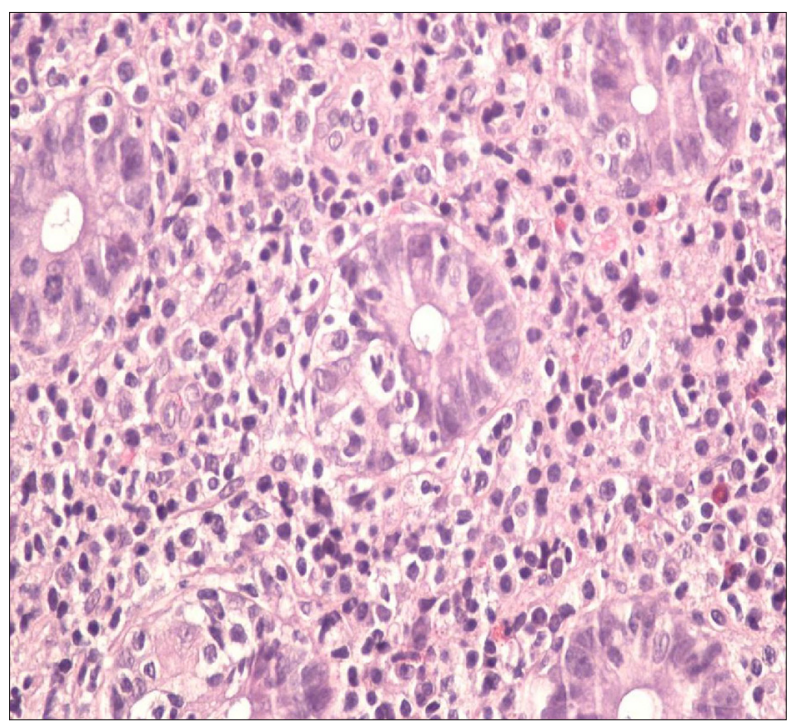

Figure 4. MALT lymphoma involving colon. There is a diffuse infiltrate comprised of small to medium sized lymphocytes with monocytoid features and plasmacytoid cells.

positive, which was checked later during the course of treatment. Bone marrow biopsy was performed for further staging and was found to be negative for any neoplastic process. The patient received two weeks of antibiotic therapy comprising of amoxicillin, clarithromycin with a proton pump inhibitor for $H$. pylori, and four cycles of rituximab. Repeat stool testing for $H$. pylori four weeks after completion of the course of antibiotics, confirmed eradication. Repeat colonoscopy after the completion of chemotherapy cycles showed complete resolution of the MALT lymphoma (Figures 6-8). 


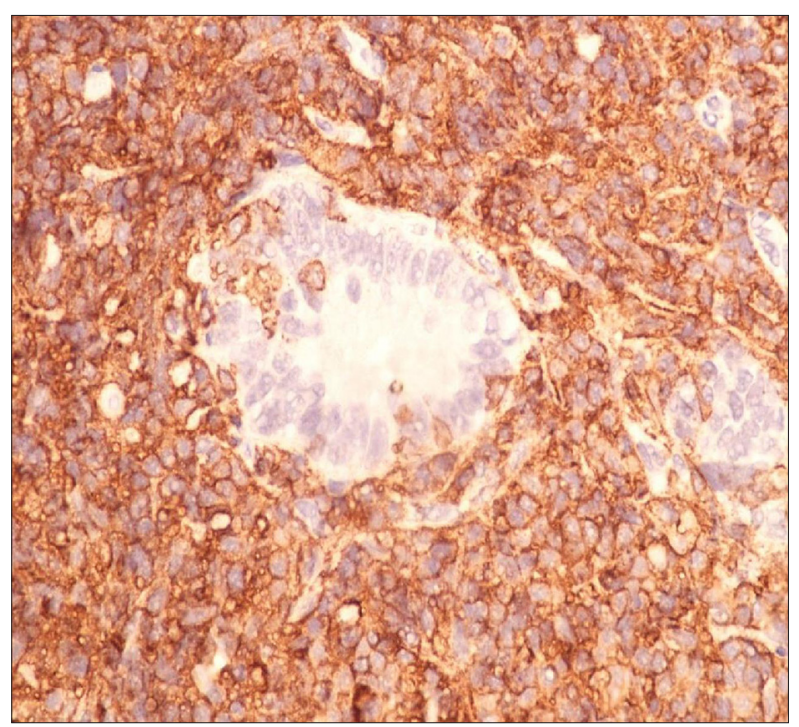

Figure 5. Immunostain CD20 show strong positivity in lymphoma cells.

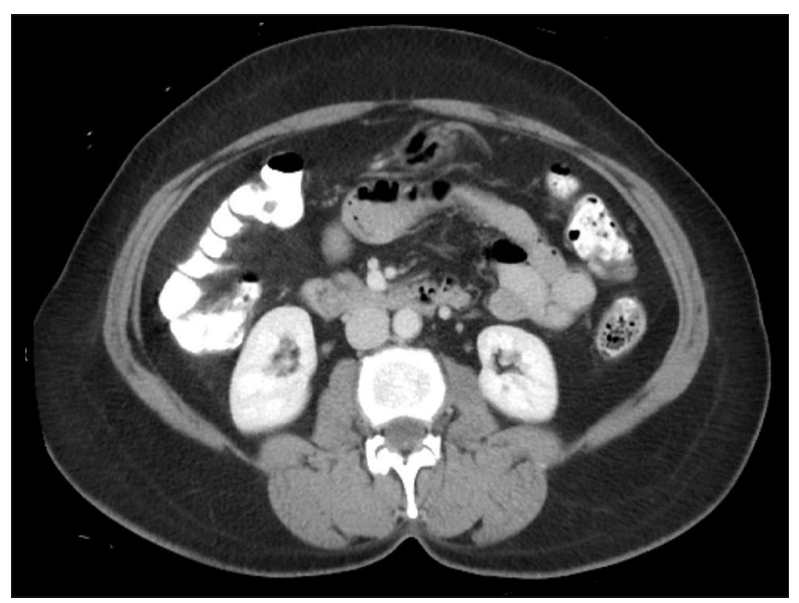

Figure 6. Computed tomography (CT) of abdomen (horizontal view) showing resolution of colonic mass at the hepatic flexure that was seen on previous imaging after completion of treatment with rituximab monotherapy.

\section{Discussion}

\section{Disease incidence and prevalence}

$\mathrm{NHL}$ is a common hematologic malignancy in the USA and worldwide. NHL has an extra nodal presentation in 25\% to $33 \%$ of patients with $\mathrm{Gl}$ tract being the most common site. Stomach is the most commonly involved part of the GI tract in about $50 \%$ of these cases [1-4], whereas small intestine is the most common site in Middle Eastern nations. Lymphomas of the Gl tract include a variety of histologic subtypes: MALT lymphoma, DLBCL, Burkitt lymphoma, enteropathy-associated T-cell lymphoma, mantle cell lymphoma, and follicular lymphoma [5].

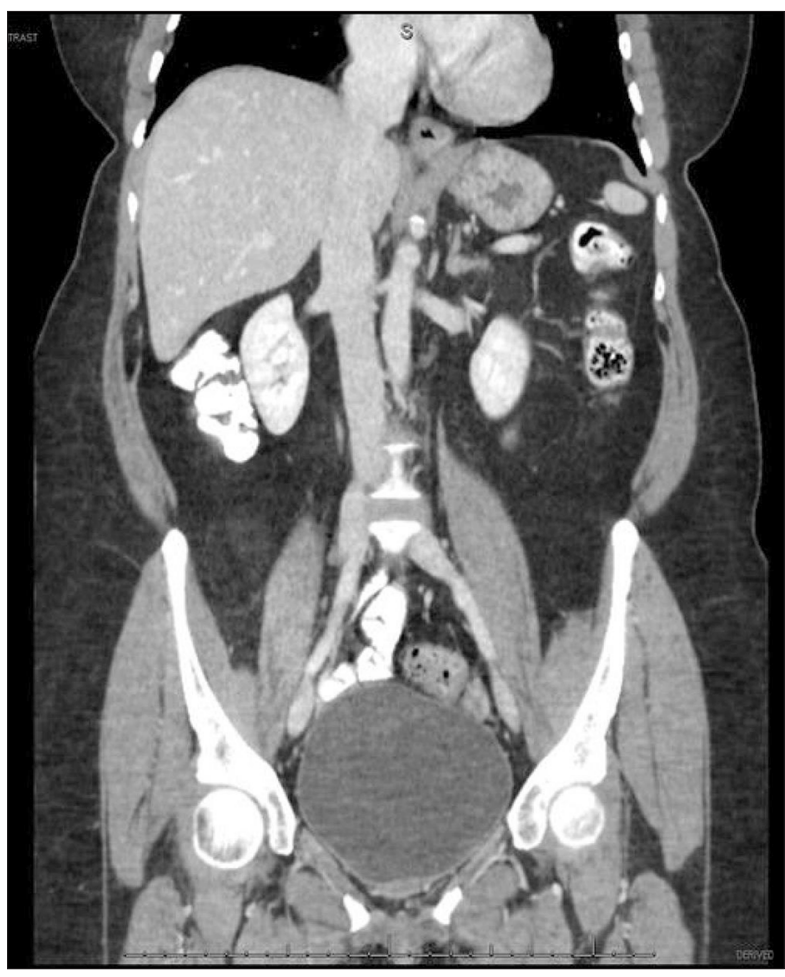

Figure 7. Computed tomography (CT) of abdomen (coronal view) showing resolution of colonic mass at the hepatic flexure that was seen on previous imaging after completion of treatment with rituximab monotherapy.

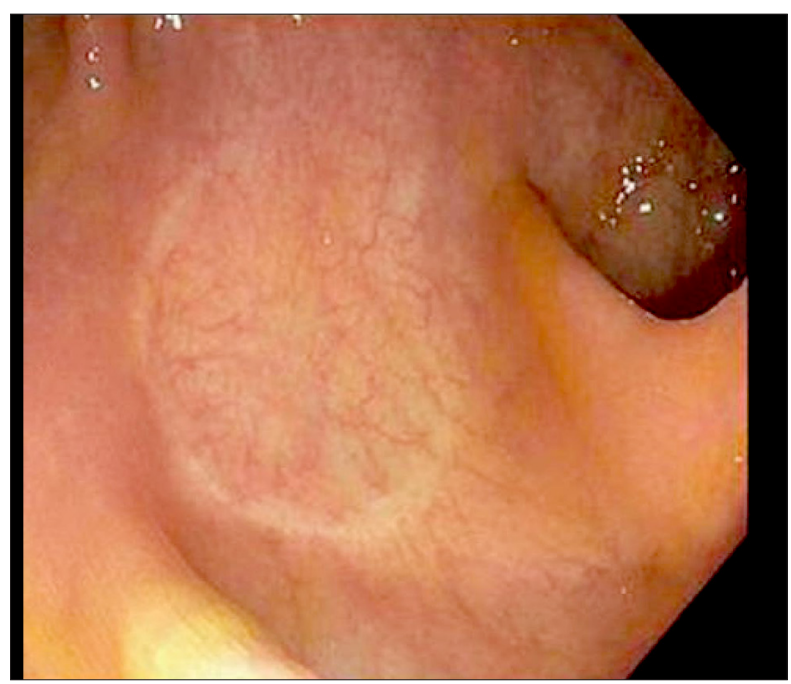

Figure 8. Endoscopic appearance of hepatic flexure after rituximab therapy completion.

MALT or extra nodal marginal zone lymphoma comprises $5 \%$ of NHL [7]. MALT lymphoma was first described by Isaacson and Wright in 1983 [8] as a low grade B cell lymphoma involving extra nodal organs [7]. The most common site of occurrence of MALT lymphoma is the stomach in $60 \%$ to $75 \%$ of cases, followed by small intestine, ileum, cecum, colon, and rectum [12,13]. 
Involvement of the esophagus has also been reported [14], as well as the extra-intestinal sites including lungs, ocular adnexa, lung breast, and skin $[6,8,15]$. The colon is involved in only $2.5 \%$ of cases making it a rare entity, and to date only a handful of cases have been reported in the medical literature $[7,11]$.

\section{Demographics and etiology}

MALT lymphomas are predominantly seen in the sixth decade of life. The mean age of presentation is 60 years. Although female predominance is seen in a 2: 1 ratio compared to males in some studies, there is no difference among the genders according to one review $[11,16-18]$.

MALT lymphoma has two types, one that originates from normally present lymphoid tissue like Peyer patches in the gut and the second that arises from acquired lymphoid tissue that develops in response to inflammation in the setting of $H$. pylori infection or autoimmune disease [6]. Pathogenesis of gastric MALT lymphoma includes chronic antigenic stimulation by $H$. pylori and subsequent chronic inflammation that leads to proliferation of $B$ cell in lymphoid tissue to MALT lymphoma. Association between extra-gastric MALT lymphoma of the small intestine and campylobacter jejuni infection has been reported $[8,10]$. Infectious etiology has not yet been established for colonic MALT lymphoma [6].

\section{Clinical presentation}

Primary colonic MALT lymphomas most commonly present with GI bleeding $[11,16,17]$. Abdominal pain, rare perforation $[6,19]$, and intussusception have also been reported [20]. Isolated primary MALT lymphoma of the colon is seen less often. It is usually present with simultaneous occurrence at other sites in the GI tract [21]; therefore, at the time of diagnosis, synchronous lesions should also be ruled out. Staging for MALT lymphomas should include gastroscopy, colonoscopy, bone marrow biopsy, and CT of thorax and abdomen $[6,15,22,23]$.

\section{Endoscopic appearance}

Endoscopic features of the MALT lymphoma of the colon are not well defined. Most often a single polypoid lesion is seen $[7,24,25]$, but multiple polypoid lesions have also been reported [20]. Colonic MALT lymphoma may also present as an ulcer or a nodule $[6,21,26]$.

\section{Treatment}

The association between gastric MALT lymphoma and chronic $H$. pylori infection is well established $[5,9,10]$. The mainstay of treatment for localized gastric MALT lymphoma is antibiotic therapy directed against $H$. pylori infection [27-29], with complete remission reported in $70 \%$ to $80 \%$ of cases [5,30-33].
If inadequate response or relapse occurs, irradiation of the stomach is indicated either alone or in combination with chemotherapy and surgery [5,34-37]. Advanced stage lymphoma requires treatment with radiotherapy or chemotherapy. If the tumor involves distant lymph nodes or extra nodal sites then the treatment comprises chemotherapy only.

Extra-gastric MALT lymphoma of the small intestine is associated with campylobacter jejuni infection $[8,10]$, but no recommendations for testing or antibiotic treatment have been made as yet and further studies are needed [38]. Response to H. pylori eradication in these cases is variable $[39,40]$. In localized lymphomas of the small intestine, resection is the preferred treatment. In a few cases, localized disease has been successfully treated with radiotherapy [5,41-43]. In cases where surgical resection is not possible due to location or spread, chemotherapy with chlorambucil or rituximab with cyclophosphamide, vincristine, and prednisone is indicated.

For colonic MALT lymphoma there is no standardized therapy and the best treatment modality has long been debated. While most cases use surgery or chemotherapy as the first-line treatment, and rarely complete resolution with $H$. pylori therapy has been reported $[17,40,44,45]$. The chemotherapy regimen comprised of mitoxantrone, chlorambucil, and prednisone has been used to successfully treat colonic MALT lymphoma [46,47]. Other regimens are chlorambucil or rituximab with cyclophosphamide, vincristine, and prednisone [5,41-43]. More recently rituximab alone as a single agent has also been used in successful treatment of colonic MALT lymphoma [48-50]. Single agent or combination chemotherapy has shown a $50 \%$ response rate $[10,51-53]$. Besides surgical resection and chemotherapy; radiation and endoscopic resection have also been employed [17,54]. Curative endoscopic resection of a large polypoid MALT lymphoma after downsizing with radiotherapy has also been reported [10].

\section{Conclusions}

Colonic MALT lymphoma is a rare type of extra nodal NHL. Unlike the prototype gastric mucosa associated lymphoid tissue lymphoma, treatment for colonic variety is not standardized. Chemotherapy, as well as surgical resection, has been used to successfully achieve cure. Recently, rituximab was been reported as a promising treatment modality as monotherapy in a few case reports. Our case not only reports a rare disease presenting as a large mass as an unusual presentation, but also reports on the successful use of novel treatments, such as rituximab, in treating colonic MALT lymphoma without recurrence.

\section{Disclosures}

None. 


\section{References:}

1. Cai S, Cannizzo F Jr., Bullard Dunn KM et al: The role of surgical intervention in non-Hodgkin's lymphoma of the colon and rectum. Am J Surg, 2007; 193: 409-12; discussion 412

2. Jemal A, Siegel R, Ward E et al: Cancer statistics, 2006. Cancer J Clin, 2006; 56: 106-30

3. Freeman C, Berg JW, Cutler SJ: Occurrence and prognosis of extranodal lymphomas. Cancer, 1972; 29: 252-60

4. Koniaris LG, Drugas G, Katzman PJ, Salloum R: Management of gastrointestinal lymphoma. J Am Coll Surg, 2003; 197: 127-41

5. Aleman BM, Haas RL, van der Maazen RW: Role of radiotherapy in the treatment of lymphomas of the gastrointestinal tract. Best Pract Res Clin Gastroenterol, 2010; 24(1): 27-34

6. Romaguera J, Hagemeister FB: Lymphoma of the colon. Curr Opin Gastroenterol, 2005; 21: 80-84

7. Hasegawa N, Kato K, Yamada K et al: Extranodal marginal zone B-cell lymphoma of mucosa-associated lymphoid tissue (MALT) of the sigmoid colon. Gastrointest Endosc, 2000; 52: 802-4

8. Shaye OS, Levine AM: Marginal zone lymphoma. J Natl Compr Cancer Netw, 2006; 4: 311-18

9. Nakamura S, Yao T, Aoyagi $\mathrm{K}$ et al: Helicobacter pylori and primary gastric lymphoma. A histopathologic and immunohistochemical analysis of 237 patients. Cancer, 1997; 79(1): 3-11

10. Piotrowski R, Kramer R, Kamal A: Image of the month. Extranodal marginal zone B-cell (mucosa-associated lymphoid tissue) lymphoma of the colon presenting as an obstructing mass. Clin Gastroenterol Hepatol, 2008; 6: e18-19

11. Chen PH, Lin YM, Yen HH: Primary mucosa-associated lymphoid tissue lymphoma of the colon. Clin Gastroenterol Hepatol, 2011; 9: e74-75

12. Bautista-Quach MA, Ake CD, Chen M, Wang J: Gastrointestinal lymphomas: Morphology, immunophenotype and molecular features. J Gastrointest Oncol, 2012; 3: 209-25

13. Ferreri AJ, Montalban C: Primary diffuse large B-cell lymphoma of the stomach. Crit Rev Oncol Hematol, 2007; 63: 65-71

14. Hosaka S, Nakamura N, Akamatsu T et al: A case of primary low grade mucosa associated lymphoid tissue (MALT) lymphoma of the oesophagus. Gut, 2002; 51: 281-84

15. Raderer $M$, Vorbeck F, Formanek $M$ et al: Importance of extensive staging in patients with mucosa-associated lymphoid tissue (MALT)-type lymphoma. Br J Cancer, 2000; 83: 454-57

16. Ahlawat $S$, Kanber Y, Charabaty-Pishvaian A et al: Primary mucosa-associated lymphoid tissue (MALT) lymphoma occurring in the rectum: A case report and review of the literature. South Med J, 2006; 99: 1378-84

17. Matsuo S, Mizuta Y, Hayashi T et al: Mucosa-associated lymphoid tissue lymphoma of the transverse colon: a case report. World J Gastroenterol, 2006; 12: 5573-76

18. Ramavaram S, Velchala N, Levy R, Rego RF: Malt lymphoma of the colon: A rare occurrence. J Gastrointest Cancer, 2014; 45(Suppl. 1): 29-32

19. Chim CS, Shek TW, Chung LP, Ho J: Gut perforation in MALT lymphoma of colon. Haematologica, 2002; 87: EIM15

20. Kimura M, Takeda T, Maekura S et al: [MALT lymphoma of large intestine as multiple large polypoid lesions]. Rinsho Byori, 1995; 43: 847-51 [in Japanese]

21. Yoshino T, Ichimura K, Mannami T et al: Multiple organ mucosa-associated lymphoid tissue lymphomas often involve the intestine. Cancer, 2001; 91: 346-53

22. Barista I, Cabanillas F, Romaguera JE et al: Is there an increased rate of additional malignancies in patients with mantle cell lymphoma? Ann Oncol, 2002; 13: 318-22

23. Brandtzaeg P, Farstad IN, Haraldsen G: Regional specialization in the mucosal immune system: Primed cells do not always home along the same track. Immunol Today, 1999; 20: 267-77

24. Dragosics B, Bauer P, Radaszkiewicz T: Primary gastrointestinal non-Hodgkin's lymphomas. A retrospective clinicopathologic study of 150 cases. Cancer, 1985; 55: 1060-73

25. Matsumoto $T$, Shimizu $M$, lida $M$ et al: Primary low-grade, B-cell, mucosaassociated lymphoid tissue lymphoma of the colorectum: Clinical and colonoscopic features in six cases. Gastrointest Endosc, 1998; 48: 501-8
26. Chim CS, Shek TW, Chung LP, Liang R: Unusual abdominal tumors: Case 3. Multiple lymphomatous polyposis in lymphoma of colon. J Clin Oncol, 2003; 21: 953-55

27. Zucca E, Copie-Bergman C, Ricardi U et al: Gastric marginal zone lymphoma of MALT type: ESMO Clinical Practice Guidelines for diagnosis, treatment and follow-up. Ann Oncol, 2013; 24(Suppl. 6): vi144-48

28. Ruskone-Fourmestraux A, Delmer A, Lavergne A et al: Multiple lymphomatous polyposis of the gastrointestinal tract: Prospective clinicopathologic study of 31 cases. Groupe D'etude des Lymphomes Digestifs. Gastroenterology, 1997; 112: 7-16

29. Moleiro J, Ferreira S, Lage P, Dias Pereira A: Gastric malt lymphoma: Analysis of a series of consecutive patients over 20 years. United European Gastroenterol J, 2016; 4: 395-402

30. Bayerdorffer E, Neubauer A, Rudolph B et al: Regression of primary gastric lymphoma of mucosa-associated lymphoid tissue type after cure of Helicobacter pylori infection. MALT Lymphoma Study Group. Lancet, 1995; 345: 1591-94

31. Wotherspoon AC, Doglioni C, Diss TC et al: Regression of primary low-grade B-cell gastric lymphoma of mucosa-associated lymphoid tissue type after eradication of Helicobacter pylori. Lancet, 1993; 342: 575-77

32. Wotherspoon AC, Ortiz-Hidalgo C, Falzon MR, Isaacson PG: Helicobacter pylori-associated gastritis and primary B-cell gastric lymphoma. Lancet, 1991; 338: $1175-76$

33. Wundisch T, Thiede C, Morgner A et al: Long-term follow-up of gastric MALT lymphoma after Helicobacter pylori eradication. J Clin Oncol, 2005; 23: $8018-24$

34. Fischbach W, Dragosics B, Kolve-Goebeler ME et al: Primary gastric B-cell lymphoma: Results of a prospective multicenter study. The German-Austrian Gastrointestinal Lymphoma Study Group. Gastroenterology, 2000; 119: 1191-202

35. Hammel P, Haioun C, Chaumette MT et al: Efficacy of single-agent chemotherapy in low-grade B-cell mucosa-associated lymphoid tissue lymphoma with prominent gastric expression. J Clin Oncol, 1995; 13: 2524-29

36. Morgner A, Schmelz R, Thiede $C$ et al: Therapy of gastric mucosa associated lymphoid tissue lymphoma. World J Gastroenterol, 2007; 13: 3554-66

37. Schechter NR, Portlock CS, Yahalom J: Treatment of mucosa-associated lymphoid tissue lymphoma of the stomach with radiation alone. J Clin Oncol, 1998; 16: 1916-21

38. Lecuit M, Abachin E, Martin A et al: Immunoproliferative small intestinal disease associated with Campylobacter jejuni. New Engl J Med, 2004; 350: 239-48

39. Grunberger B, Wohrer S, Streubel B et al: Antibiotic treatment is not effective in patients infected with Helicobacter pylori suffering from extragastric MALT lymphoma. J Clin Oncol, 2006; 24: 1370-75

40. Nakase H, Okazaki K, Ohana M et al: The possible involvement of micro-organisms other than Helicobacter pylori in the development of rectal MALT lymphoma in H. pylori-negative patients. Endoscopy, 2002; 34: 343-46

41. Amouri A, Chtourou L, Mnif L et al: [MALT lymphoma of the rectum: a case report treated by radiotherapy]. Cancer Radiother, 2009; 13: 61-64

42. Yamashita H, Nakagawa K, Asari T et al: Radiotherapy for 41 patients with stages I and II MALT lymphoma: A retrospective study. Radiother Oncol, 2008; 87: 412-17

43. Ha CS, Cho MJ, Allen PK et al: Primary non-Hodgkin lymphoma of the small bowel. Radiology, 1999; 211: 183-87

44. Matsumoto T, lida M, Shimizu M: Regression of mucosa-associated lymphoid-tissue lymphoma of rectum after eradication of Helicobacter pylori. Lancet, 1997; 350: 115-16

45. Inoue F, Chiba T: Regression of MALT lymphoma of the rectum after antiH. pylori therapy in a patient negative for H. pylori. Gastroenterology, 1999; 117: $514-15$

46. Gezen C, Kement M, Oncel $M$ et al: Mucosa associated lymphoid tissue lymphoma of the colon: A case report. Cases J, 2009; 2: 9316

47. Sallach S, Schmidt T, Pehl C et al: Primary low-grade B cell non-Hodgkin's lymphoma of MALT type simultaneously arising in the colon and in the lung: Report of a case. Dis Colon Rectum, 2001; 44: 448-52

48. Kim MH, Jung JT, Kim EJ et al: A case of mucosa-associated lymphoid tissue lymphoma of the sigmoid colon presenting as a semipedunculated polyp. Clin Endosc, 2014; 47: 192-96 
49. Raderer $M$, Jager $G$, Brugger $S$ et al: Rituximab for treatment of advanced extranodal marginal zone $B$ cell lymphoma of the mucosa-associated lymphoid tissue lymphoma. Oncology, 2003; 65: 306-10

50. Cohen SM, Petryk M, Varma M et al: Non-Hodgkin's lymphoma of mucosaassociated lymphoid tissue. Oncologist, 2006; 11: 1100-17

51. Tsai HK, Li S, Ng AK et al: Role of radiation therapy in the treatment of stage I/II mucosa-associated lymphoid tissue lymphoma. Ann Oncol, 2007; 18: $672-78$
52. Jager G, Neumeister $P$, Brezinschek $R$ et al: Treatment of extranodal marginal zone B-cell lymphoma of mucosa-associated lymphoid tissue type with cladribine: A phase II study. J Clin Oncol, 2002; 20: 3872-77

53. Wohrer S, Drach J, Hejna $M$ et al: Treatment of extranodal marginal zone B-cell lymphoma of mucosa-associated lymphoid tissue (MALT lymphoma) with mitoxantrone, chlorambucil and prednisone (MCP). Ann Oncol, 2003; 14: 1758-61

54. Li B, Shi YK, He XH et al: Primary non-Hodgkin lymphomas in the small and large intestine: Clinicopathological characteristics and management of 40 patients. Int J Hematol, 2008; 87: 375-81 